Language and Cognition 13 (2021), 34-65. doi:10.1017/langcog.2020.25

(C) UK Cognitive Linguistics Association 2020. This is an Open Access article, distributed under the terms of the Creative Commons Attribution licence (http://creativecommons.org/licenses/ by/4.0/), which permits unrestricted re-use, distribution, and reproduction in any medium, provided the original work is properly cited.

\title{
Variable motion event encoding within languages and language types: a usage-based perspective*
}

\author{
WOJCIECH LEWANDOWSKI \\ Leipzig University \\ (Received 26 December 2019 - Revised 14 Fune 2020 - Accepted 15 fune 2020 - \\ First published online 6 August 2020)
}

ABSTRACT

Speakers of the world's languages differ in the ways they talk about directed motion. Speakers of satellite-framed languages (S-languages; e.g., English) typically conflate Path and Manner in a single clause (e.g., run out), whereas speakers of verb-framed languages (V-languages; e.g., Spanish) tend to convey Path and Manner in two different clauses (e.g., salir corriendo 'exit running'). Herein, we ask whether speakers also show systematic variability within particular languages and language types in their directed motion descriptions. We examine this question by comparing oral narratives of adult native speakers of one $\mathrm{V}$-language (Spanish) and two S-languages (German, Polish) $(\mathrm{N}=15)$, where each subject provided a simultaneous description of an ongoing animated video depicting self- (e.g., jump into the river) and caused-motion (e.g., throw a stone into the river) events. Our results showed strong evidence for both intra-typological and languageinternal variability, especially in the extent to which the Manner component is encoded. Overall, the locus of Path encoding (e.g., verb, prefix, particle) and the conceptual structure of motion events (i.e., self-motion, caused-motion) were two key factors that influenced the speakers' choice of lexicalization pattern. We discuss the implications of our findings, which (i) suggest a more nuanced typology of motion events that expands the binary distinction between $\mathrm{V}$ - vs. S-languages - in line with earlier work on

[*] This research was supported by the European Union's Horizon 2020 research and innovation programme under the Marie Sklodowska-Curie grant agreement H2020MSCA.IF-2014-658596, the Beatriu de Pinós Postdoctoral Grant (2017 BP 00053) from the Catalan Agency for Management of University and Research Grants and the European COFUND programme, and the Grant FFI2017-82460-P from the Spanish State Research Agency and the European FEDER Funds. Address for correspondence: Leipzig University, Institut für Angewandte Linguistik und Translatologie, D-04081 Leipzig. e-mail: woj.lewandowski@gmail.com 
intra-typological variability, and (ii) highlight the relevance of such a nuanced typology for motion cognition.

KEYWORDS: spatial language, self-motion, caused-motion, intratypological variation, intra-linguistic variation, motion cognition.

\section{Introduction}

The expression of directed motion has been one of the topics that has caught researchers' attention for the past four decades. According to Talmy (1978), a motion event comprises four basic components: (i) Figure, i.e., an entity that moves, (ii) Motion of the Figure, (iii) Ground, i.e., a reference point with respect to which the Figure moves, and (iv) Path, i.e., the trajectory along which the motion takes place. In addition, a motion event may include a co-event, a semantic component that typically conveys information about the Manner or the Cause of motion. For example, the sentence $\mathcal{F}$ ohn ran into the room explicitly mentions all these elements: the Figure ( $F o h n$ ), the Ground (room), the Path (into), and Motion conflated with the co-event (i.e., the Manner; ran).

Languages show systematic cross-linguistic variation in their encoding of directed motion events, particularly in the ways they map Path and Manner onto surface expressions. According to Talmy $(1991,2000)$, speakers of satelliteframed languages (S-languages; e.g., English, German, Polish) typically use a conflated strategy, encoding Manner in the main verb and Path in a satellite around the main verb (e.g., particle, prefix) within a single clause (e.g., run into, juтр ир). In contrast, speakers of verb-framed languages (V-languages; e.g., Japanese, Spanish, Turkish) generally rely on a separated strategy, expressing Path in the main verb, and Manner in an additional subordinated clause (e.g., Sp. entrar corriendo 'enter running', salir saltando 'exit jumping'); see also Malblanc (1968), Tesnière (1959), and Vinay and Darbelnet (1958) for previous discussions of motion event typology, especially with respect to French as compared to English and German. Because the encoding of Manner outside the main verb involves additional syntactic constituents that impose increased processing demands, speakers of V-languages frequently leave out Manner altogether from their descriptions of motion (Özçalışkan, 2009, 2016; Özçalışkan \& Slobin, 1999, 2003; Slobin, 1991).

Most of the previous work on motion events focused on languages belonging to different types (e.g., V- vs. S-language) and provided compelling evidence for the aforementioned coding patterns: when talking about directed motion, speakers of S-languages predominantly used manner verbs, whereas speakers of V-languages largely relied on path verbs (Allen et al., 2007; Berman \& Slobin, 1994; Gennari, Sloman, Malt, \& Fitch, 2002; Hickmann, Taranne, \& Bonnet, 2009; Naigles, Eisenberg, Kako, Highter, \& McGraw, 1998; Strömqvist \& Verhoeven, 2004). Importantly, however, even though languages 
generally show preference for one type of lexicalization pattern over another, there is also evidence indicating that languages display significant intratypological variation, i.e., variation within the same typological group, especially with respect to the degree to which they elaborate Path and Manner (see Goschler \& Stefanowitsch, 2013, for a recent collection of studies). For example, Ibarretxe-Antuñano (2004, 2009) suggested that languages can be placed on a continuum of Path salience that cross-cuts the binary split between $\mathrm{V}$ - and S-languages. By way of illustration, although Spanish and Basque are both V-languages, speakers of Spanish tend to limit themselves to conveying Path in the verb, while speakers of Basque frequently add additional Path segments such as source and goal outside the verb, resulting in more elaborated Path descriptions (see also Özçalışkan, 2009, for a similar pattern in Turkish). Similarly, languages from the same typological affiliation can differ in their ability to express Manner. For instance, previous findings suggest that, when talking about self-motion, German speakers tend to encode more specific Manner dimensions in the main verb than Polish speakers, who generally make use of a smaller variety and amount of manner verbs (Lewandowski \& Mateu, 2016; Lewandowski \& Özçalışkan, 2019). A similar pattern of differences has held true for other combinations of Slavic and Germanic languages such as, e.g., Polish vs. English (Kopecka, 2010; Slobin, Ibarretxe-Antuñano, Kopecka, \& Majid, 2014), Serbo-Croatian vs. English (Filipović, 2007), and Russian and Polish vs. English, Dutch, and Swedish (Koptjevskaja-Tamm, Divjak, \& Rakhilina, 2010), with Germanic languages consistently showing a higher degree of Manner salience compared to Slavic languages; see also Ragnarsdóttir and Strömqvist (2004) for an intra-genetic comparison of Manner encoding between Icelandic and Swedish, i.e., within the Germanic group.

Moreover, given that the affiliation to one or the other typological group is based on the most frequent encoding strategy, languages rarely if ever rely on their typical lexicalization pattern exclusively. For example, although English is predominantly an S-language, it has a number of path verbs, both Latinate (e.g., enter, exit, ascend, etc.) and of Germanic origin (e.g., rise, leave), which appear in $\mathrm{V}$-framed type constructions (e.g., The plane ascended to 3000 feet; Stefanowitsch, 2013). In a similar vein, speakers of V-languages occasionally use the conflated strategy, especially if the motion event does not imply the crossing of a spatial boundary (e.g., Sp. correr hacia la puerta 'run toward the door', caminar hasta la colina 'walk up to the hill'; Aske 1989; Slobin \& Hoiting, 1994).

In short, although languages can be classified as either $\mathrm{S}$ - or $\mathrm{V}$-framed based on their most frequent lexicalization pattern, speakers of each language type also rely on packaging strategies that do not fully fit the characteristics of their typological affiliation. However, despite a growing body of research on patterns of motion expression, our understanding of the effects of variability within particular languages and language types is far from complete. For example, 
most of the previous studies predominantly investigated the expression of self-motion (i.e., motion instigated by the Figure itself, e.g., enter the room), while considerably less attention has been paid to the encoding of causedmotion (i.e., motion instigated by an external force, e.g., push the chair into the room), one notable exception to this general trend being the expression of placement events (e.g., Bowerman, Brown, Eisenbeiss, Narasimhan, \& Slobin, 2002; Gullberg \& Narasimhan, 2010; Kopecka \& Narasimhan, 2012). In addition, the most common speech production tasks consisted of descriptions of motion scenes in which subjects were not faced with strict time limits while elicitation methods that involved the added pressure of time constraints were used rarely (but see Pourcel, 2005, for an exception). To be more specific, in previous experiments, in which the elicitation stimuli were either pictures (e.g., Berman \& Slobin, 1994; Cadierno, 2010; Özçalışkan, 2015; Strömqvist \& Verhoeven, 2004) or video clips (e.g., Hendriks \& Hickmann, 2015; Lewandowski \& Özçalışkan, 2019; Stam, 2006), experimenters allowed the subjects to provide a motion event description in an unhurried manner after visualization. If the stimuli consisted of a series of isolated (decontextualized) scenes, participants were given time to describe each scene one at a time before proceeding to the next scene (e.g., Hendriks \& Hickmann, 2015; Özçalışkan, 2015). In turn, if the stimuli consisted of a series of connected events (i.e., a short story), the subjects were asked to perform a free prose recall task after visually inspecting the entire sequence of stimuli (e.g., Berman \& Slobin, 1994; Stam, 2006).

In this study, we aim to further contribute to the ongoing debate on motion event encoding by integrating in a single research design for both (i) self- and caused-motion events and (ii) inter- and intra-typological comparisons, using simultaneous commentary of an ongoing video clip as our elicitation task. The decision to use a simultaneous 'live commentary' task instead of a recall task after visualization was based on the assumption that the added pressure of time constraints would minimize the effects of planned performance, thereby leading to more spontaneous speech production, typical of everyday communicative interactions (cf., e.g., Ochs, 1979; Roberts \& Kirsner 2000). As such, our data collection methodology adds a qualitative aspect to previous speech production tasks, which in the majority of cases did not require participants to cope with the unpredictable demands of unplanned performance.

We focus on two S-languages, German and Polish, and one V-language, Spanish. German and Spanish are two representative examples of S- and V-languages, respectively (e.g., Bamberg, 1994; Cifuentes-Férez, 2008; Harr, 2012; Sebastián \& Slobin, 1994; Talmy, 2000). Polish, in turn, despite its typological similarity to German, differs from prototypical S-languages in its lexicalization of Manner, with less specific encoding of this semantic component in the main verb (Kopecka, 2010; Lewandowski \& Mateu, 2016). Hence, the combination of languages involved in our study constitutes a relevant 
proving ground for the effect of both inter- and intra-typological factors in the linguistic construal of motion.

Starting with inter-typological variation, following earlier work (e.g., Berman \& Slobin, 1994; Strömqvist \& Verhoeven, 2004; Talmy, 2000), we expect German and Polish speakers to display greater reliance on manner tokens (i.e., number of manner verbs) and types (i.e., variety of manner verbs) than Spanish speakers in their descriptions of self-motion. Although earlier work on inter-typological contrasts in the expression of caused-motion is relatively scarce compared to earlier work on self-motion, we expect the same pattern of variation to apply to caused-motion descriptions based on the available empirical evidence (Hendriks \& Hickmann, 2015; Hendriks, Hickmann, \& Demagny, 2008; Ji, Hendriks, \& Hickmann, 2011).

Turning next to intra-typological variation, based on previous work by Kopecka (2010) and Lewandowski and Mateu (2016), we expect greater use of manner tokens and types in German compared to Polish in self-motion descriptions. We also explore the possibility that caused-motion events will show the same pattern of similarities and differences (i.e., greater reliance on manner tokens and types in German compared to Polish).

Turning last to intra-linguistic variation, we predict that speakers of all three languages will display greater reliance on manner tokens in their causedmotion descriptions as compared to their self-motion descriptions. This prediction is based on earlier studies on physical and metaphorical motion (e.g., Hendriks \& Hickmann, 2015; Özçalışkan, 2005), suggesting that speakers of both $\mathrm{V}$ - and S-languages increase the number of manner verbs (i.e., manner tokens) in describing events from a caused motion perspective. However, we cannot predict if the same pattern of intra-linguistic variation also applies to the variety of manner verbs (i.e., manner types), given the lack of systematic of evidence in earlier work on this subject.

\section{Methods}

\subsection{SA M P LE}

The participants included 15 adult German native speakers $\left(\mathrm{M}_{\mathrm{age}}=25\right.$, range $=$ $19-33$; 8 females), 15 adult Polish native speakers $\left(M_{\text {age }}=23\right.$, range $=20-24$; 9 females $)$, and 15 adult native Spanish native speakers $\left(M_{\text {age }}=21\right.$, range $=20-$ 36; 10 females). Data were gathered at different universities in Germany, Poland, and Spain. Most of the participants were university students, and 4 participants were teaching assistants with postgraduate degrees. The sample size was based on earlier work by Özçalışkan (2009), which showed that 10 subjects per group would provide a minimum of $84 \%$ power to detect reliable effects at $p<.05\left(\eta^{2}=0.08 ; \mathrm{n}=10 /\right.$ group $)$. 


\subsection{DATA COLLECTION}

Participants were interviewed individually in a laboratory room. They were asked to watch a silent 360-second-long extract from Charlie Chaplin's City Lights (cf. Pourcel, 2005) and to provide a 'live commentary' of what was happening in the video to an experimenter. The elicitation stimulus depicted both self-motion events ( 6 different manners: step, rush, swim, jump, stagger, walk; 6 different paths: forward, backward, upward, downward, into, out) and caused-motion events ( 6 different Manners: push, pull, throw, submerge, drop, drag; 6 different Paths: forward, backward, upward, downward, into, out); see Appendix I for a sequence of events included in the stimulus video. Participants' responses were videotaped.

\subsection{DATA COD I N G}

Responses were transcribed by native speakers of the corresponding languages and divided into clauses. A clause unit was defined as a main verb and its associated arguments/adjuncts (e.g., Germ. Sie laufen die Treppe runter 'They run down the stairs'; Pl. Schodza po schodach 'They walk down the stairs'; Sp. Entran corriendo en el agua 'They enter the water running'). Each clause was classified as either self-motion (i.e., events involving self-instigated movement; e.g., Germ. Sie springen aus dem Wasser raus 'They jump out of the water'; Pl. Wychodza z rzeki 'They walk out of the river'; Sp. Salen del agua 'They exit the water') or caused-motion (i.e., events involving other-instigated movement; e.g., Germ. Er wirft den Mann ins Wasser 'He throws the man into the water'; Pl. Wrzuca kamien do rzeki 'He throws the stone into the river'; Sp. Tira al hombre al agua 'He throws the man into the water'). Each clause unit was further coded for verb type. Following earlier work (e.g., Özçalışkan, 2004), motion verbs were grouped as either manner verbs (e.g., Germ. klettern 'climb', Pl. biegać 'run', Sp. empujar 'push') or non-manner verbs (i.e., path verbs; e.g., Sp. entrar 'enter', Germ. kommen 'come', and neutral verbs; e.g., Sp. ir 'go', Pl. ruszać się 'move'). The Manner category included descriptions in which Manner and Path were conveyed in a single clause (i.e., the conflated strategy; e.g., Germ. Er klettert hoch 'He climbs up'; Pl. Wbiegt do rzeki 'He ran into the river'; Sp. Empuja a Chaplin al agua 'He pushes Chaplin into the water'), while the non-manner category included descriptions in which Manner was either not expressed or was expressed in a separate subordinate clause (i.e., the separate strategy; e.g., Germ. Er kommt 'He comes'; Pl. Rusza się do tylu 'He moves backward'; Sp. Entra corriendo 'He enters running'). Given our interest in directed motion events, manner-only clauses (e.g., Germ. Er springt 'He jumps'; Pl. Biegnie 'He runs'; Sp. Se tambalea 'He wobbles') were not coded. Reliability was assessed by three independent coders (one per language) who were blind to the hypotheses of our study. The first coder coded all responses, and the 
independent coders coded $20 \%$ of the data, which included 3 randomly selected participants in each language. Agreement between coders was $92 \%$.

\subsection{ANALYSIS}

We analyzed between- and within-language differences in the use of motion verbs separately for tokens and types. To check predictions on the token level we fit a Bayesian mixed model with a binomial link function (logistic regression) as implemented in the R-package brms (Bürkner, 2018), which provides an interface to the Stan programming language (https://mc-stan.org/). To be more specific, we modeled the probability of an uttered verb to be a manner verb. Our model includes two fixed effects, namely language with three levels, that is, German, Polish, and Spanish, and event type with two levels, that is, selfmotion and caused-motion. As random variables, we implemented the speaker only. The uttered verb itself is either manner or non-manner and is not suitable as a random variable in this setting. We introduced a random slope of event type on the speaker. The specific predictions were checked on the basis of post-hoc tests computed by the emmeans R package (Length, 2019).

The predictions regarding the number of types could not be addressed in this standard framework given that their distribution does not easily fit into any of the standard distributions from the exponential family. Therefore, we decided to use the non-parametric Wilcoxon rank sum test. Since the typebased predictions are very simple and persist only to very specific subsets of the data, this can be done with little disadvantage. The data along with the statistical analyses can be found online at <https://osf.io/gp46y/?view_only= bac22d906e9f460f81bfc0e6b70974e7>.

\section{Results}

\subsection{TOKENS}

Starting with verb tokens, we first looked at inter-typological variation and found the expected differences in the encoding of motion events. Specifically, German and Polish speakers showed greater reliance on manner tokens than Spanish speakers when talking about both self- and caused-motion, resulting in more conflated descriptions in German and Polish compared to Spanish. When contrasting Spanish speakers against German and Polish speakers for self-motion, we observe a point estimate of 0.091, meaning that the odds for the utterance of a manner verb for describing self-motion events in Spanish is approximately an eleventh of that in Polish and German. The credibility interval reaches from 0.04 up to 0.15 , which is well below one, corroborating our predictions; see Figure 1 for a summary of our results for manner tokens. In a similar vein, when contrasting Spanish speakers against German and 


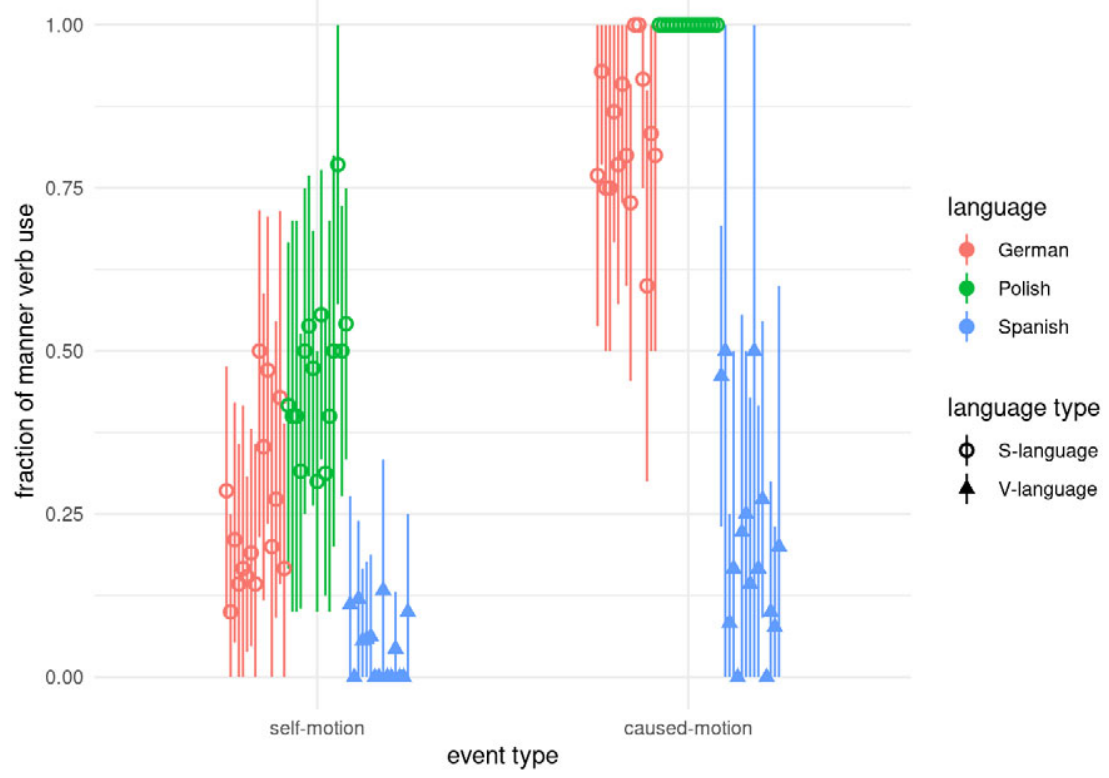

Fig. 1. Fraction of manner verbs used by German, Polish, and Spanish speakers in self- and caused-motion descriptions.

Note. Each circle/triangle represents the fraction of manner verbs used by a specific speaker, color coded for the language, while the shape of the symbols represents the language type. Error bars are bootstrapped confidence intervals.

Polish speakers for caused-motion, we observe a point estimate of 0.0004 , with the credibility interval reaching from $1.7 \times 10^{-9}$ up to 0.0072 , a result that is also in line with our predictions.

Next turning to intra-typological variation, contrary to our predictions, German speakers did not show greater reliance on manner tokens than Polish speakers in their descriptions of self- or caused-motion events. Instead, the opposite pattern became evident: regardless of event type, Polish speakers showed a higher proportion of manner tokens than German speakers, resulting in greater reliance on the conflated pattern in Polish as compared to German. For self-motion, the confidence interval reaches from 0.22 up to 0.56 , centered around an odds ratio of 0.38 . For caused-motion, the confidence interval reaches from $2.3 \times 10^{-15}$ up to 0.02 , centered around an odds ratio of $8.06 \times 10^{-5}$.

Turning last to intra-linguistic variation, in line with our hypothesis we found that event type (i.e., self-motion, caused-motion) had an effect on the packaging of motion elements. Specifically, German, Polish, and Spanish speakers increased their use of manner tokens when talking about causedmotion, resulting in more conflated caused-motion descriptions compared to 
self-motion descriptions. If we look at the overall effect of the variable event type we get a clear result for the odds ratio between self-motion and causedmotion with a credibility interval from $1.6 \times 10^{-6}$ up to 0.037 , centered around an odds ratio of 0.0056 . Since this ignores clearly visible interactions it is not a well interpretable result. If we make separate tests for our three languages, we get an estimate of 0.06 for German, $1.3 \times 10^{-5}$ for Polish, and 0.2 for Spanish. This result still fully vindicates our predictions. Examples of self- and causedmotion descriptions produced by German, Polish, and Spanish speakers are provided in Tables 2-4 in Appendix II, while Table 6 in Appendix IV summarizes the mean frequencies of clauses with separated and conflated packaging of motion in each language.

\subsection{TY P ES}

Turning next to verb types, we first analyzed inter-typological variability and found the expected contrasts in the expression of motion events: German and Polish speakers produced a significantly greater variety of manner verbs compared to Spanish speakers in both their self- (Spanish vs. Polish: W =1 95.5, $p<.001$; Spanish vs. German: $\mathrm{W}=218, p<.001)$ and caused-motion descriptions (Spanish vs. Polish: $\mathrm{W}=208.5, p<.001$; Spanish vs. German: $\mathrm{W}$ $=224, p<.001$ ); see Figure 2 for a summary of our results for verb types.

Our analysis also confirmed the predicted intra-typological variation: German speakers produced a greater variety of manner verbs than Polish speakers when talking about both self- $(\mathrm{W}=176, p=.003)$ and caused-motion $(\mathrm{W}=182.5, p=$ $.001)$. This pattern is consistent with earlier work on intra-typological variation between Slavic and Germanic languages in the expression of self-motion (Kopecka, 2010; Lewandowski \& Mateu 2016; Slobin et al., 2014), and extends this earlier work to the domain of caused-motion, indicating that intratypological variation in S-languages can be found across the two event types.

We last examined whether the production of verb types varied by event perspective (i.e., self- vs. caused-motion) and found evidence for an effect: German, Polish, and Spanish native speakers produced a greater variety of manner verbs in their caused-motion descriptions compared to self-motion descriptions $(\mathrm{V}=583.5, p<.001)$. These findings thus extend previous results

for manner tokens (Lewandowski \& Özçalıșkan, 2018) to manner types; see Table 7 in Appendix $V$ for a complete list of manner and path verbs produced by speakers of each language.

\section{Discussion}

In this study, we asked whether speakers of German, Polish (both S-languages), and Spanish (a V-language) exhibit inter-typological, intra-typological, and 


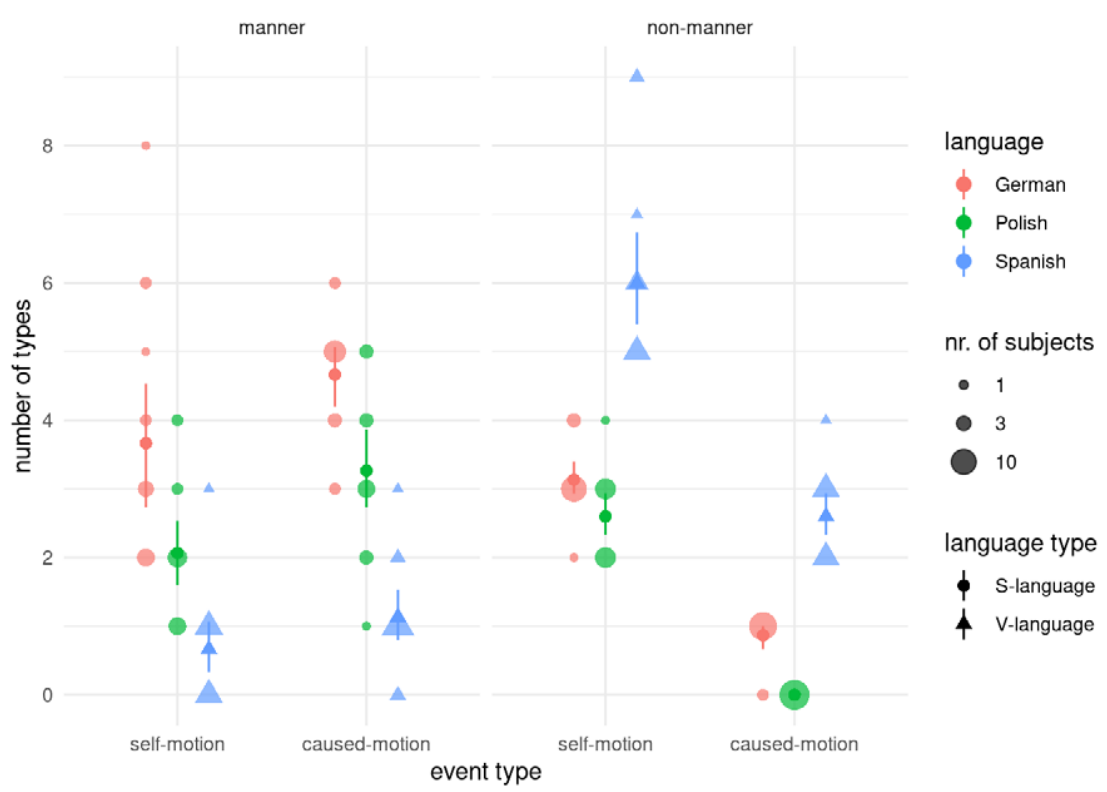

Fig. 2. The number of verb types.

Note. Each blob corresponds to a set of speakers using the same number of types in the given combination of variables. The number of speakers per blob is indicated by its size. Error bars are bootstrapped confidence intervals.

language-internal variation in their linguistic construal of motion events. Our analysis of simultaneous verbalizations of an ongoing video sequence produced by 15 German, 15 Polish, and 15 Spanish adult native speakers provided compelling evidence for both intra-typological and language-internal, as well as inter-typological variability in the expression of motion.

\subsection{IN TER - T Y P O L O G I C A L VAR I A T I O N}

Starting with inter-typological variation, German and Polish speakers showed greater preference for manner types and tokens (i.e., the conflated strategy; e.g., Germ. Der Mann schreitet die Treppe runter 'The man strides down te stairs', Chaplin zieht ihn aus dem Wasser 'Chaplin pulls him out of the water'; Pl. Doplynęli do brzegu 'They swam up to the shore', Rzucit line na ziemię 'He threw the rope onto the floor') than Spanish speakers, who mostly relied on the separated packaging strategy (e.g., Sp. Chaplin baja las escaleras 'Chaplin descends the stairs', Apartó la maleta 'He moved the suitcase away'). This pattern was consistent across the two event types, i.e., self- and caused-motion. As such, our analysis provides empirical evidence that the previously observed 
typological differences between $\mathrm{V}$ - and S-languages in the expression of selfmotion (Allen et al., 2007; Berman \& Slobin, 1994; Strömqvist \& Verhoeven, 2004) extend to caused-motion events, a finding that is consistent with earlier work by Hendriks and Hickmann (2015), Hendriks et al. (2008), and Ji et al. (2011).

\subsection{INTRA-T Y POL OGICAL VARIATION}

Turning next to intra-typological variation, we found that German speakers produced greater diversity of manner verbs (i.e., verb types) than Polish speakers regardless of event type. This pattern was reversed for the number of manner verbs (i.e., verb tokens), with German speakers showing lower reliance on manner tokens than Polish speakers when talking about both self-and caused-motion.

With regard to type frequency, our data indicate that the contrasting use of manner types between German and Polish was not random but followed a specific pattern. While both German and Polish speakers made extensive use of general manner verbs (i.e., first-tier verbs according to Slobin's, 1997, classification; e.g., Germ. Und dann springen sie rein 'And then, they jump into'; P1. Wkoczyli do wody 'They jumped into the water'; Germ. Er wirft seinen Stock weg 'He throws his stick away'; Pl. Wrzucit Chaplina do wody 'He threw Chaplin into the water'), German speakers relied on more specific manner verbs (i.e., second-tier verbs according to Slobin's, 1997, classification; e.g., 'stagger', 'stumble', 'nudge', 'thrust', etc.) at higher rates than Polish speakers; see also, e.g., Cifuentes-Férez (2010) and Slobin et al. (2014), for further classifications of different types of Manner. Therefore, German speakers used a narrative style that is richer in Manner specifications (i.e., more granular Manner descriptions) compared to Polish speakers. How can we explain the existence of different degrees of Manner granularity in languages than belong to the same typological group? We propose that two closely inter-related factors are at work here: (i) codability effects, such as constraints on Manner/Path combinability and accessibility of manner verbs in the lexicon, and (ii) attention allocation during verbalization (i.e., thinking-for-speaking; Slobin, 1996).

Starting with codability effects, Polish speakers had no choice but to exclude from their motion descriptions many of the Manners used in the German narratives due to heavy restrictions on Manner/Path combinability (e.g., Germ. Er hat Chaplin ins Wasser reingeschubst 'He nudged Chaplin into the water' vs. Pl. *wszturchnać 'nudge into'; Germ. Er stolpert hinaus 'He stumbles out' vs. Pl. *wypotknać się 'stumble out', etc.). ${ }^{1}$ This finding is consistent with

[1] Following conventional notations, we use an asterisk to indicate ungrammaticality. 
earlier work (Filipović, 2007; Lewandowski \& Mateu, 2016) that demonstrated that prefixes, the typical locus of Path encoding in Polish (Kopecka, 2004; Lewandowski, 2014a, 2014b, 2020) show more restricted compatibility with verbs than particles and prepositional phrases, the typical locus of Path encoding in German (Bamberg, 1994; Harr, 2012).

A smaller inventory of manner verbs in Polish is another possible reason why Polish speakers produced fewer Manner types than German speakers. For example, verbs such as schmeißen 'chuck', shieben 'thrust', hieven 'heave', hüpfen 'hop', widely used by German speakers, could not have been employed by Polish speakers for the simple reason that no direct equivalents are available in the Polish lexicon. We know from previous studies on inter-typological variation in the expression of motion that grammatical restrictions on Manner encoding have an effect on the size of the manner-of-motion lexicon. S-languages, with Manner encoded in the main verb, have a richer lexicon of manner verbs than V-languages, which typically encode Manner in an optional adjunct (Slobin, 2006; Verkerk, 2013). Our study thus extends these earlier findings by suggesting that, even within the same typology, languages can have diverse manner verb lexicons, depending on the grammatical restrictions they impose on the lexicalization of Manner.

Turning now to the effects of attention allocation during verbalization, Polish speakers attended to a smaller variety of Manner distinctions than German speakers even in cases where a Polish equivalent of a German verb could have been used. For example, German speakers frequently employed verbs such as 'slip' (e.g., Der Stein ist runtergerutscht 'The stone slipped down'), 'rip' (e.g., Der Mann hat Chaplin die Schnur aus der Hand gerissen 'He ripped Chaplin's cord away'), 'pack' (e.g., Er hat alles ins Koffer gepackt 'He packed everything into the suitcase'), and others. Although these verbs are available in the Polish lexicon, and, importantly, they can readily combine with prefixes (e.g., ześlizgnać się 'slip down'; wpakować 'pack into'; wydrzeć 'rip away'), they were not used by Polish speakers. It follows, then, that Polish speakers were attuned to a smaller range of Manner dimensions than German speakers, even if no codability restrictions were imposed by the linguistic system. This observation is consistent with Slobin's (1996) thinking-forspeaking hypothesis, and extends its applicability to the domain of intratypological variation. According to Slobin (1996), typological variation affects cognition, particularly during online production of speech. More specifically, the habitual way of encoding events biases speakers to those conceptual components of the event that are easily codable in the language they speak. For example, when talking about motion, speakers of S-languages pay greater attention to the Manner of motion than speakers of $\mathrm{V}$-languages, an attentional bias that results from the codification of Manner in different clausal constituents (i.e., main verb vs. adjunct, respectively). As such, the 
speakers' choice to include certain properties of the event while omitting others depends not only on how salient the property is but also on how easily encodable the property is in a given language. Following this line of reasoning, it can be claimed that German speakers displayed stronger attentional bias toward specific Manner dimensions compared to Polish speakers because German provides more accessible means, both lexical and morphological, for the expression of specific Manner distinctions than Polish.

Nevertheless, despite the greater diversity of manner verbs in German narratives, German speakers relied on a smaller number of manner verbs (i.e., manner tokens) than Polish speakers. Why, then, was the lexicalization pattern found for verb types reversed for verb tokens? One possible explanation is that, when describing motion scenes, German speakers relied on path tokens to a larger extent than Polish speakers, resulting in a lower proportion of manner tokens in German compared to Polish. Specifically, the German participants commonly employed two path verbs in their descriptions of self-motion, namely fallen 'fall' (e.g., Er ist ins Wasser gefallen 'He fell into the water') and kommen 'come' (e.g., Er kommt aus dem Wasser 'He comes out of the water'), and one path verb in their descriptions of caused-motion, namely holen 'bring, fetch' (e.g., Er holt das Seil 'He brings the rope'). Only the equivalent of fallen 'fall' was used by the Polish group (e.g., Wpadt do wody 'He fell into the water'), because Polish has no equivalent for the deictic path verbs kommen 'come' and holen 'bring, fetch' (Lewandowski, 2007, 2010, 2014c). Having fewer path verbs at their disposal, Polish speakers had no alternative but to increase their use of manner verbs. For example, to convey the content of kommen, the Polish group systematically used the basic manner verb chodzic' 'walk' combined with a path satellite (e.g., Mężzyzna wychodzi z wody 'The man comes out of the water', lit. 'The man walks out of the water'), thus increasing the number of manner tokens but not manner types.

These results are contradictory to those presented in the study by Lewandowski and Mateu (2016), who found that German motion descriptions not only included more manner types but also more manner tokens than Polish motion descriptions. One factor that might explain this divergence is the difference in research design. Lewandowski and Mateu compared German and Polish translations of Tolkien's The Hobbit. They focused on nine passages with particularly rich manner information. As such, when adapting the source text to the target language, translators had no alternative but to make frequent use of manner verbs to preserve the semantic content of the original passages. Our study, on the other hand, required participants to provide a free description of motion scenes, thereby allowing them the opportunity to exclude Manner from their narratives. 


\subsection{LAN GUAGE-INTERNAL VARIAT I O N}

Turning last to language-internal variation, we found that speakers across the three languages encoded a significantly greater number (i.e., manner tokens) and variety (i.e., manner types) of Manner distinctions in the main verb in their caused-motion descriptions compared to their self-motion descriptions. Previous research showed that caused-motion events elicit a higher number of manner verbs than self-motion events (Hendriks \& Hickmann, 2015; Lewandowski \& Özçalışkan, 2018; Özçalışkan, 2005). Our results thus extend these previous findings by showing that, when talking about caused-motion, speakers not only increase their use of manner tokens but also manner types.

However, why do caused-motion events show a higher degree of Manner encoding than self-motion events? Self-motion refers to an agents' selfinstigated movement and, as such, it only includes one participant, i.e., the Figure. In contrast, caused-motion events describe other-instigated movement and, as such, they include one further participant, namely, an external force that causes the Figure to move. As a consequence, while self-motion events can only specify the way in which the Figure moves (i.e., Manner of motion, e.g., He jumped into the water), caused-motion events are able to specify both the way in which the Figure moves (e.g., Fohn rolled the ball across the room) and the way in which the figure is caused to move (i.e., Manner of causation; e.g., Fohn kicked the ball across the room); see, e.g., Rappaport Hovav and Levin (1998). Therefore, the possibility of expressing this additional piece of information may have been one reason why speakers across the three languages increased their use of manner verbs in their caused-motion descriptions. In fact, Manner of causation is one important feature that constitutes an essential semantic attribute of the majority of caused-motion verbs involved in our study (e.g., Germ. schubsen 'push, nudge', stoßen 'push, bump', werfen 'throw', etc.; Pl. pchać 'push', rzucać 'throw', (s) tracić 'knock (over)', etc.; Sp. empujar 'push'; soltar 'drop', tirar 'throw, pull', etc.).

However, encoding Manner dimensions in the main verb in Spanish causedmotion descriptions (e.g., Tiró la piedra al agua 'He threw the stone into the water', Empujó a Chaplín al rio 'He pushed Chaplin into the river', etc.) is at odds with the fact that V-languages typically lexicalize Path but not Manner in the main verb. One plausible explanation for this pattern could be that causedmotion events bring about a strong notion of dynamicity (Rohde, 2001). Specifically, given that the external agent exerts force upon the Figure to initiate its movement, it also determines the spatial source of the motion event, thus supplying a sense of directionality. We have some evidence from previous work that manner verbs that evoke directionality can occasionally appear in self-motion descriptions in V-languages (e.g., Sp. correr a la cocina 'run to the kitchen', saltar al agua 'jump into the water' vs. *bailar a la cocina 'dance to the 


\section{LE W A N D O W S K I}

kitchen', *tambalear a la habitación 'stagger into the room'; Lewandowski \& Mateu, forthcoming; Naigles et al., 1998; Özçalışkan, 2015; Pedersen, 2014). Our results thus extend these earlier findings by indicating that directional manner verbs can be found in motion constructions across the two event types, i.e., self- and caused-motion, in V-languages.

Surprisingly, we also observed that German and Polish speakers showed a pronounced tendency toward the use of non-manner verbs (i.e., the separated packaging strategy) in their self-motion descriptions, a pattern that is not fully in line with earlier research, which exposed a clear inclination toward the conflated lexicalization strategy among speakers of S-languages (e.g., Strömqvist \& Verhoeven, 2004). For example, some of the scenes included in our elicitation task could have been described in two ways: either by employing a manner verb combined with a path satellite (i.e., conflated strategy) or by encoding Path information only (i.e., separated strategy): cf. Germ. Er gleitet ins Wasser 'He slides into the water' vs. Er fällt ins Wasser 'He falls into the water', Er kriecht die Kante hoch 'He crawls up the ledge' vs. Er kommt aus dem Wasser raus 'He comes out of the water'; Pl. Wrzuca się do wody 'He plunges into the water' vs. Wpada do wody 'He falls into the water'. Both German and Polish speakers showed preference for the latter strategy: only 65 out of 257 German and 101 out of 224 Polish self-motion descriptions were Manner/Path conflated clauses.

It should be noted, however, that previous studies typically did not require participants to respond with the added pressure of restricted time, while our elicitation task (i.e., a simultaneous commentary of an ongoing video clip) naturally resulted in heavy time constraints on the subjects' responses. We know from psychological research that humans process information selectively by focusing on properties that are more central and tuning out those that are more peripheral (Pashler, 1998). We also know that time pressure may additionally intensify reduction of information processing (Maule, Hockey, \& Bdzola, 2000). Consistent with these findings, our results may indicate that speakers tend to reduce the conceptual complexity of motion events as a way to adapt to time constraints. Because Path constitutes the core element of a motion event (Talmy, 2000), it logically follows that both German and Polish speakers were biased toward excluding Manner (and not Path) from their narratives. An alternative explanation could be that there is a general tendency in oral narratives, independent of time constraints, to omit Manner information if an alternative Path-only strategy is available and Manner is not particularly relevant to the discourse (see Filipović, 2007; McNeill \& Duncan, 2000; Stefanowitsch, 2013, for similar phenomena in other S-languages). Further research is needed to understand the relative effect of time constraints on the speakers' choice of lexicalization patterns. 
4.4. GENERAL D ISCUSSION

Taken together, our findings suggest that the extent to which Talmy's (2000) typology exerts itself in language use is influenced by additional factors that expand the binary distinction between V-vs. S-languages. The locus of Path encoding (i.e., verb vs. prefix vs. particle/prepositional phrase) gives rise to inter- and intra-typological variation, while event type (self- vs. causedmotion) gives rise to language-internal variation. In addition, speech modality (e.g., oral vs. written narratives; narratives with vs. without time constraints, etc.) appears to be a third important factor influencing the packaging of motion elements - a possibility that remains to be further explored in future work.

Starting with inter- and intra-typological variation, our data strongly indicate that the locus of Path encoding affects the expression of Manner. Spanish, typically conveying Path in the main verb, imposes the tightest typological constraints on Manner encoding. In contrast, German and Polish, which lexicalize Path outside the main verb, leave the verb free to encode Manner. However, there is a split between Polish, typically expressing Path in morphologically bound prefixes, and German, typically expressing Path in morphologically independent particles and prepositional phrases. Specifically, Polish imposes heavier restrictions on Manner codability than German, resulting in distinct 'thinking-for-speaking' patterns, with Polish speakers attending to less diverse Manner dimensions than German speakers. These results are consistent with earlier work which provided some evidence that speakers of languages such as Russian, Serbian, and Latin, which typically encode Path in prefixes, convey less specific Manner distinctions than speakers of languages such as English, Dutch, and Swedish, typically conveying Path in particles and prepositional phrases (see Filipović, 2007, for Serbo-Croatian and English; Iakovleva, 2012, for Russian and English; Koptjevskaja-Tamm et al., 2010, for Russian, Polish, English, Dutch, and Swedish; and Iacobini \& Corona, 2016, for Latin). In addition, we know from work on lexical semantics and construction grammar that in languages such as English and German, both typically encoding Path in particles and prepositional phrases, motion constructions are particularly flexible in that they not only combine with motion verbs but also with non-motion verbs lexicalizing highly specific Manner information (e.g., Eng. Rainwater whistled into the house, He crashed his car into a cemetery; Germ. Das Fahrrad ist in die Altstadt gequietscht 'The bike squeaked into the old town', Er schmetterte den Ball über das Netz 'He smashed the ball over the net'; see Goldberg, 1995; Haselbach, 2018; Levin, 1993). Consistent with our findings, these verbs are banned from occurring in motion constructions in languages such as, for example, Polish and Russian, which both typically encode Path in prefixes (e.g., Pl. *W'swisnat do pokoju 'He whistled into the 


\section{LE W A N D O W S K I}

room', *Whukną samochód do cmentarza 'He crashed his car into a cemetery'; Rus. *Velosiped $v$ "skripel $v$ staryj gorod 'The bike squeaked into the old town').

That being the case, the observed differences in Manner expression between German and Polish may illustrate a broader division between S-languages that typically encode Path in morphologically bound elements such as prefixes (e.g., Polish, Russian, Serbian, Latin) and S-languages that typically encode Path in morphologically independent elements such as particles and prepositional phrases (e.g., German, Dutch, English, Swedish). It could be hypothesized, then, that the tighter the link between Path and the main verb, the less the ability to encode Manner and, conversely, the looser the link between Path and the main verb, the more the ability to encode Manner. That is, on one extreme would be V-languages, in which Path and verb are the same element. These languages impose the tightest restrictions on Manner encoding by allowing only a limited set of directional manner verbs to occur in the main verb slot. Next to these languages would be $\mathrm{S}$-languages in which the locus of Path is an element that is morphologically bound to the verb, i.e., a prefix. These languages encode more specific Manner information than $\mathrm{V}$-languages but impose fairly tight restrictions on motion verbs encoding rich Manner information. Finally, at the other extreme would be S-languages in which the locus of Path is an element that is morphologically independent from the verb, i.e., a particle and/or a prepositional phrase. These languages allow the encoding of a particularly wide variety of Manner dimensions.

However, consistent with language-internal variability, motion constructions associated with morphologically bound and morphologically free elements can co-exist in a given language. For example, although German predominantly encodes Path in particles and prepositional phrases, this language also uses (to a lesser extent) directional prefixes. In line with the restrictions on Manner/Path combinability outlined above, German prefixes typically combine with a narrower range of manner verbs than German particles and prepositional phrases (Lewandowski \& Mateu, forthcoming). As such, strictly speaking, the constraints on Manner encoding apply to particular constructions rather than to particular languages.

It should be stressed, however, that there is not necessarily a positive correlation between diversity and number of manner verbs. For example, German speakers produced more manner types but fewer manner tokens than Polish speakers in their directed motion descriptions. Conversely, Polish speakers produced fewer manner types but more manner tokens than German speakers, when talking about both self- and caused-motion. We proposed that this pattern arose, primarily, as a result of greater use of path verbs in German compared to Polish. More important, these findings show that, while the locus of Path encoding seems to be a good predictor of Manner diversity in motion 
descriptions, the amount of Manner information may be dependent on additional factors. As such, future work examining these additional factors is needed to gain a better understanding of the extent to which Manner is encoded in the two types of S-languages.

Turning now to language-internal variability, our findings showed that not only languages as a whole but also different event types (argument structure constructions in Goldberg's, 1995, terms) within particular languages can display variable degrees of Manner salience. For example, our data, along with evidence from earlier research (Lewandowski \& Özçalışkan, 2018; Özçalışkan, 2005), suggest that caused-motion events elicit greater diversity and number of manner verbs than self-motion events regardless of language type, which is a pattern that we attributed to differences in event structure between self- and caused-motion. Our study also demonstrated that speakers of S-languages may convey Path in the main verb at higher rates than one might expect on the basis of Talmy's (2000) typology, particularly when describing self-motion events. We suggested that one possible factor leading to an extensive use of path verbs in S-languages may be related to constraints on processing time - a hypothesis that remains to be further investigated.

Slobin (2004) proposed that the world's languages can be arranged along a cline of Manner salience, with some languages encoding more specific Manner distinctions than others. Our study adds to this line of research by showing that Manner salience is a more complex and nuanced issue than it may seem at first glance: there can be significant differences between variety vs. amount of Manner information encoded in a given language, and the same language can also show different degrees of Manner saliency depending on event type.

These findings may prove fruitful for future research on linguistic relativity. According to linguistic relativity, the structure of a language influences the way its speakers view the world (Lucy, 1996; Whorf, 1956). As mentioned before, Slobin (1996) proposed that language-specific patterns in the encoding of motion affect non-verbal cognition - but only during online language processing (thinking-for-speaking). Studies examining the effect of inter-typological contrasts in the encoding of self-motion on visual perception, similarity judgments, and gesture provide empirical support for Slobin's hypothesis. For example, when visually inspecting a motion scene, or when comparing two motion scenes that differ either in Manner or Path, participants displayed a bias toward either Manner or Path, depending on their language type, if the task involved verbal encoding. However, they did not display such bias if the task did not involve verbalization (Gennari et al., 2002; Hohenstein, 2005; Papafragou, Hulbert, \& Trueswell, 2008). In a similar vein, participants showed language-specific gesture patterns only when gesture was produced with speech (i.e., co-speech gesture), but not when gesture was produced without speech (Özçalışkan et al., 2016). 
It is likely, of course, that the preferred lexicalization patterns have no or little long-term effect on non-verbal cognition. However, the presence of such effects has been exposed for at least some other cognitive domains, such as color (Regier \& Kay, 2009), number (Gordon, 2004), time (Boroditsky, 2001), object position (Koster \& Cadierno, 2018), spatial frames of reference (Brown \& Levinson, 1993; Pederson et al., 1998), and count/mass distinctions (Imai \& Gentner, 1997), etc. (see Gleitman \& Papafragou, 2013, for a recent review). As such, it is also possible that the motion lexicalization patterns that are supposed to be prototypical in a given language type (i.e., either $\mathrm{V}$ - or S-framing) are simply not ubiquitous enough to influence non-linguistic thought (Goschler \& Stefanowitsch, 2013; Pavlenko \& Volynsky, 2015). This possibility should not be ruled out. Hence, future work should take into account not only the coarse-grained inter-typological contrasts but also the more nuanced intra-typological and language-internal variability in order to advance our understanding of the relationship between language and motion cognition. For example, earlier work on the effects of lexicalization patterns on non-verbal cognition in S- vs. V-languages largely focused on self-motion events (e.g., Papafragou et al., 2008; Özçalışkan, Lucero, \& Goldin-Meadow, 2016). However, the domain of self-motion might not be a good testing ground for cognitive biases toward Manner in S-languages because, as our study showed, speakers of S-languages may rely on the Manner/Path conflated pattern far less frequently than is commonly assumed. The domain of caused-motion, in contrast, may be a more promising avenue for investigating the effects of S-framing on non-linguistic conceptualization, because in language use manner verbs (i.e., the conflated pattern) might be more ubiquitous in caused-motion events as opposed to self-motion events.

The assumption that Manner and Path form uniform categories is another possible limitation that might have skewed the results of studies on linguistic relativity. With respect to Manner, a more fruitful line of inquiry might be one that focuses on those manner types that are particularly salient in a given language. For example, it is unlikely that speakers of S-languages encoding path in prefixes will display cognitive bias toward highly specific Manner information given its relatively low frequency in discourse. However, the opposite may prove true for languages encoding path in morphologically independent elements (i.e., particles, prepositional phrases), given that these languages systematically encode more elaborated Manner distinctions.

In conclusion, our study suggests that the two-way distinction between Sand $\mathrm{V}$-languages may be insufficient to not only identify the whole range of variation in the encoding of motion events but also to test the effects of language on motion cognition. Although we only focused on three languages, German, Polish, and Spanish, our results suggest, in line with earlier work (e.g., Ibarretxe-Antuñano, 2009; Slobin, 2004), that the ways in which motion 


\section{VARIABLE MOTION EVENT ENCODING}

is encoded in these languages may be characteristic of a more nuanced typological classification than the dichotomy of V-and S-languages. Specifically, languages such as Hebrew, Japanese, and Turkish pattern together with Spanish and hence belong to the V-framed type. Next, languages such as Latin, Russian, and Serbian pattern together with Polish and hence belong to the 'weak' type of S-language, lexicalizing path in morphologically bound elements. Finally, languages such as English, Dutch, and Swedish pattern together with German and hence belong to the 'strong' type of S-language, lexicalizing path in morphologically independent elements. Therefore, future work that extends our findings to these groups of languages is needed to advance our understanding of variation patterns in motion event encoding and their effect on motion cognition.

\section{REFERENCES}

Allen, S., Özyürek, A., Kita, S., Brown, A., Furman, R., Ishizuka, T. \& Fujii, M. (2007). Language-specific and universal influences in children's syntactic packaging of Manner and Path: a comparison of English, Japanese and Turkish. Cognition 102(1), 16-48.

Aske, J. (1989). Path predicates in English and Spanish: a closer look. In Proceedings of the fifteenth annual meeting of the Berkeley Linguistics Society (pp. 1-14). Online < https://doi.org/ 10.3765/bls.v15i0.1753>.

Bamberg, M. (1994). Development of linguistic forms: German. In R. Berman \& D. Slobin (eds), Relating events in narrative: a cross-linguistic developmental study (pp. 189-238). Hillsdale, NJ: Lawrence Erlbaum.

Berman, R. \& Slobin, D. (1994). Relating events in narrative: a cross-linguistic developmental study. Hillsdale, NJ: Lawrence Erlbaum.

Boroditsky, L. (2001). Does language shape thought? Mandarin and English speakers' conception of time. Cognitive Psychology 43(1), 1-22.

Bowerman, M., Brown, P. Eisenbeiss, S., Narasimhan, B. \& Slobin, D. I. (2002). Putting things in places. developmental consequences of linguistic typology. In E. V. Clark (ed.), Space in language: location, motion, path, and manner (pp. 1-29). Stanford, CA: Center for the Study of Language \& Information.

Brown, P. \& Levinson, S. C. (1993). Linguistic and nonlinguistic coding of spatial arrays: explorations in Mayan cognition. Working Paper 24, Cognitive Anthropology Research Group, Max Planck Institute for Psycholinguistics. Online < https://pure.mpg.de/pubman/ faces/ViewItemOverviewPage.jsp?itemId=item_825550>.

Bürkner, P.-C. (2018). Advanced Bayesian multilevel modeling with the R package brms. The $R$ Fournal 10(1), 395-411.

Cadierno, T. (2010). Motion in Danish as a second language: Does the learner's L1 make a difference? In Z. H. Han \& T. Cadierno (eds), Linguistic relativity in second language acquisition: thinking for speaking (pp. 1-33). Clevedon: Multilingual Matters.

Cifuentes-Férez, P. (2008). Motion in English and Spanish: a perspective from Cognitive Linguistics, typology and psycholinguistics. Unpublished doctoral dissertation, University of Murcia <https://www.tdx.cat/bitstream/handle/10803/10816/CifuentesFerez.pdf>.

Cifuentes-Férez, P. (2010). The semantics of the English and Spanish motion verb lexicons. Review of Cognitive Linguistics 8(2), 233-271.

Filipović, L. (2007). Talking about motion: a cross-linguistic investigation of lexicalization patterns. Amsterdam: John Benjamins.

Gennari, S. P., Sloman, S. A., Malt, B. C. \& Fitch, W. (2002). Motion events in language and cognition. Cognition 83(1), 49-79. 


\section{LE W A N D O W S K I}

Gleitman, L. R. \& Papafragou, A. (2013). Relations between language and thought. In D. Reisberg (ed.), The Oxford handbook of cognitive psychology (pp. 504-523). New York: Oxford University Press.

Goldberg, A. (1995). Constructions: a Construction Grammar approach to argument structure. Chicago, IL: Chicago University Press.

Gordon, P. (2004). Numeric cognition without words: evidence from Amazonia. Science 306 (5695), 496-499.

Goschler, J. \& Stefanowitsch, A. (2013). Variation and change in the encoding of motion events. Amsterdam: John Benjamins.

Gullberg, M. \& Narasimhan, B. (2010). What gestures reveal about how semantic distinctions develop in Dutch children's placement verbs. Cognitive Linguistics 21(2), 239-262.

Harr, A.-K. (2012). Language-specific factors in first language acquisition: the expression of motion events in French and German. Berlin: Mouton De Gruyter.

Haselbach, B. (2018). How to dance: on the unergative and unaccusative nature of German manner of motion verbs. Paper presented at the workshop Unergative Predicates: Architecture and Variation, Bilbao, Spain. Online <https://ehutb.ehu.eus/video/5a6f13d4f82b2b970b8b47d9>.

Hendriks, H. \& Hickmann, M. (2015). Finding one's path into another language: on the expression of boundary crossing by English learners of French. Modern Language Journal 99(S1), 14-31.

Hendriks, H., Hickmann, M. \& Demagny, A. C. (2008). How English native speakers learn to express caused motion in English and French. Acquisition et Interaction en Langue Étrangère 27, 15-41.

Hickmann, M., Taranne, P. \& Bonnet, P. (2009). Motion in first language acquisition: manner and path in French and English child language. Fournal of Child Language 36(4), 705-741.

Hohenstein, J. M. (2005). Language-related motion event similarities in English- and Spanishspeaking children. Fournal of Cognition and Development 6(3), 403-425.

Iacobini, C. \& Corona, L. (2016). 'Romanes eunt domus': Where you can go with Latin morphology; variation in motion expression between system and usage. In Proceedings of the 10th Mediterranean Morphology Meeting (pp. 73-87). Online <https://pdfs.semantic scholar.org/8de9/e166d8fcf68a3e6201c85251425e9bc85462.pdf?_ga=2.120286792.1720360297 .1594742248-2058165728.1589555862>.

Iakovleva, T. (2012). Typological constraints in foreign language acquisition: the expression of voluntary motion by upper intermediate and advanced Russian learners of English. Language, Interaction, and Acquisition 3(2), 231-260.

Ibarretxe-Antuñano, I. (2004). Motion events in Basque narratives. In S. Strömqvist \& L. Verhoeven (eds), Relating events in narrative: typological and contextual perspectives (pp. 89-111). Hillsdale, NJ: Lawrence Erlbaum.

Ibarretxe-Antuñano, I. (2009). Path salience in motion events. In J. Guo et. al. (eds), Crosslinguistic approaches to the psychology of language: research in the tradition of Dan Isaac Slobin (pp. 403-414). New York: Psychology Press.

Imai, M. \& Gentner, D. (1997). A crosslinguistic study of early word meaning: universal ontology and linguistic influence. Cognition 62(2), 169-200.

Ji, Y., Hendriks, H. \& Hickmann, M. (2011). The expression of caused motion events in Chinese and in English: some typological issues. Linguistics 49(5), 1041-1076.

Kopecka, A. (2004). Étude typologique de l'expression de l'espace: Localisation et déplacement en français et en polonais. Unpublished doctoral dissertation, Université Lumière Lyon 2. Online <https://theses.univ-lyon2.fr/documents/lyon2/2004/kopecka_a\#p=0\&a=top>.

Kopecka, A. (2010). Motion events in Polish: lexicalization patterns and the description of Manner. In V. Hasko \& R. Perelmutter (eds), New approaches to Slavic verbs of motion (pp. 225-247). Amsterdam: John Benjamins.

Kopecka, A. \& Narasimhan, B. (eds) (2012). Events of putting and taking: a crosslinguistic perspective. Amsterdam: John Benjamins.

Koptjevskaja-Tamm, M., Divjak, D. \& Rakhilina, E. V. (2010). Aquamotion verbs in Slavic and Germanic. In V. Hasko \& R. Perelmutter (eds), New approaches to Slavic verbs of motion (pp. 315-341). Amsterdam: John Benjamins. 


\section{VARIABLE MOTION EVENT ENCODING}

Koster, D. \& Cadierno, T. (2018). Is perception of placement universal? A mixed methods perspective on linguistic relativity. Lingua 207, 23-37.

Length, R. (2019). Emmeans: Estimated Marginal Means, aka Least-Squares Means. R package version 1.4.3.01. Online https://CRAN.R-project.org/package=emmeans $>$.

Levin, B. (1993). English verb class and alternations: a preliminary investigation. Chicago, IL: University of Chicago Press.

Lewandowski, W. (2007). Toward a comparative analysis of coming and going verbs in Spanish, German, and Polish. Unpublished MA thesis, Autonomous University of Barcelona. Online <https://core.ac.uk/download/pdf/13283487.pdf>.

Lewandowski, W. (2010). Questioning the universality of deictic oppositions: COME and GO in Polish, Spanish, and other languages. In I. Navarro i Ferrando \& A. J. Silvestre López (eds), Sistemas lingüisticos y perspectiva cognitiva (pp. 75-93). Valencia: Tirant Lo Blanch.

Lewandowski, W. (2014a). La alternancia locativa en castellano y polaco: Un análisis tipológicoconstruccional. Unpublished doctoral dissertation, Autonomous University of Barcelona. Online <https://ddd.uab.cat/record/127128>.

Lewandowski, W. (2014b). The locative alternation in verb-framed vs. satellite-framed languages: a corpus study of Spanish and Polish. Studies in Language 38(4), 890-921.

Lewandowski, W. (2014c). Deictic verbs: typology, thinking for speaking and SLA. SKY Fournal of Linguistics 27, 43-65.

Lewandowski, W. (2020). Bilingual patterns of path encoding: a study of Polish L1-German L2 and Polish L1-Spanish L2 speakers. International Review of Applied Linguistics in Language Teaching. Online https://doi.org/10.1515/iral-2019-0127.

Lewandowski, W. \& Mateu, J. (2016). Thinking for translating and intra-typological variation in satellite-framed languages. Review of Cognitive Linguistics 14(1), 185-208.

Lewandowski, W. \& Mateu, J. (forthcoming). Motion events again: delimiting constructional patterns. Lingua.

Lewandowski, W. \& Özçalışkan, Ș. (2018). How event perspective influences speech and co-speech gestures about motion. Fournal of Pragmatics 128, 22-29.

Lewandowski, W. \& Özçalıșkan, Ş. (2019). How language type influences patterns of motion expression in bilingual speakers. Second Language Research. Online https://doi.org/10.1177/ 0267658319877214.

Lucy, J. A. (1996). The scope of linguistic relativity: an analysis and review of empirical research. In J. J. Gumperz \& S. C. Levinson (eds), Rethinking linguistic relativity (pp. 37-69). Cambridge: Cambridge University Press.

Malblanc, A. (1968). Stylistique comparée du français et de l'allemand. Paris: Didier.

Maule, A. J., Hockey, G. R. J. \& Bdzola, L. (2000). Effects of time-pressure on decision making under uncertainty: changes in affective state and information processing strategy. Acta Psychologica 104(3), 283-301.

McNeill, D. \& Duncan, S. D. (2000). Growth points in thinking-for-speaking. In D. McNeill (ed.), Language and gesture (pp. 141-161). Cambridge: Cambridge University Press.

Naigles, L. R., Eisenberg, A. R., Kako, E. T., Highter, M. \& McGraw, N. (1998). Speaking of motion: verb use in English and Spanish. Language and Cognitive Processes 13(5), 521-549.

Ochs, E. (1979). Planned and unplanned discourse. In T. Givón (ed.), Syntax and semantics vol. 12: Discourse and syntax (pp. 51-80). New York: Academic Press.

Özçalıșkan, Ș. (2004). Typological variation in encoding the manner, path, and ground components of a metaphorical motion event. Annual Review of Cognitive Linguistics 2(1), 73-102.

Özçalışkan, Ș. (2005). Metaphor meets typology: ways of moving metaphorically in English and Turkish. Cognitive Linguistics 16(1), 207-246.

Özçalıșkan, Ș. (2009). Learning to talk about spatial motion in language-specific ways. In J. Guo, E. Lieven, S. Ervin-Tripp, N. Budwig, K, Nakamura \& Ş. Özçalıșkan (eds), Crosslinguistic approaches to the psychology of language: research in the tradition of Dan Isaac Slobin (pp. 263-276). New York: Psychology Press.

Özçalıșkan, Ş. (2015). Ways of crossing a spatial boundary in typologically distinct languages. Applied Psycholinguistics 36(2), 485-508. 


\section{LE W A N D O W S K I}

Özçalıșkan, Ș. (2016). Do gestures follow speech in bilinguals' description of motion? Bilingualism: Language and Cognition 19(3), 644-653.

Özçalışkan, Ș., Lucero, C. \& Goldin-Meadow, S. (2016). Does language shape silent gesture? Cognition 148, 10-18.

Özçalıșkan, Ş. \& Slobin, D. (1999). Learning 'how to search for the frog': expression of manner of motion in English, Spanish and Turkish. In A. Greenhill, H. Littlefield \& C. Tano (eds), Proceedings of the 23rd Annual Boston University Conference on Language Development (pp. 541-552). Somerville, MA: Cascadilla Press.

Özçalıșkan, Ș. \& Slobin, D. (2003). Codability effects on the expression of manner of motion in Turkish and English. In A. S. Özsoy, D. Akar, M. Nakipoğlu-Demiralp, E. Erguvanl1-Taylan \& A. Aksu-Koç (eds), Studies in Turkish linguistics (pp. 507-512). Istanbul: Boğaziçi University Press.

Papafragou, A., Hulbert, J. \& Trueswell J. (2008). Does language guide event perception? Evidence from eye movements. Cognition 108(1), 155-184.

Pashler, H. (1998). The psychology of attention. Cambridge, MA: MIT Press.

Pavlenko, A. \& Volynsky, M. (2015). Motion encoding in Russian and English: moving beyond Talmy's Typology. Modern Language fournal 99(S1), 32-48.

Pedersen, J. (2014). Variable type framing in Spanish constructions of directed motion. In H. Boas \& F. Gonzálvez-García (eds), Romance perspectives on Construction Grammar (pp. 269-306). Amsterdam: John Benjamins.

Pederson, E., Danziger, E., Wilkins, D., Levinson, S., Kita, S. \& Senft, G. (1998). Semantic typology and spatial conceptualization. Language 74(3), 557-589.

Pourcel, S. (2005). Relativism in the linguistic representation and cognitive conceptualisation of motion events across verb-framed and satellite-framed languages. Unpublished doctoral dissertation, University of Durham. Online <http://etheses.dur.ac.uk/2747/>.

Ragnarsdóttir, H. \& Strömqvist, S. (2004). Time, space and manner in Icelandic and Swedish. In S. Strömqvist \& L. Verhoeven (eds), Relating events in narrative: typological and contextual perspectives (pp. 113-141). Hillsdale, NJ: Lawrence Erlbaum.

Rappaport Hovav, M. \& Levin, B. (1998). Building verb meanings. In M. Butt \& W. Geuder (eds), The projection of arguments: lexical and compositional factors (pp. 97-134). Stanford, CA: CSLI.

Regier, T. \& Kay, P. (2009). Language, thought and color: Whorf was half right. Trends in Cognitive Sciences 13(10), 439-446.

Roberts, B. \& Kirsner, K. (2000). Temporal cycles in speech production. Language and Cognitive Processes 15(2), 129-157.

Rohde, A. (2001). Analyzing path: the interplay of verbs, prepositions and constructional semantics. Unpublished doctoral dissertation, Rice University, Houston, TX. Online <https:// scholarship.rice.edu/handle/1911/18015>.

Sebastián, E. \& Slobin, D. (1994). Development of linguistic forms: Spanish. In R. A. Berman \& D. I. Slobin (eds), Relating events in narrative: a crosslinguistic developmental study (pp. 239-284). Hillsdale, NJ: Lawrence Erlbaum.

Slobin, D. (1991). Learning to think for speaking: native language, cognition and rhetorical style. Pragmatics 1(1), 7-29.

Slobin, D. I. (1996). From 'thought and language' to 'thinking for speaking'. In J. J. Gumperz \& S. C. Levinson (eds), Rethinking linguistic relativity (pp. 70-96). Cambridge: Cambridge University Press.

Slobin, D. I. (1997). Mind, code, and text. In J. Bybee, S. Thompson \& J. Haiman (eds), Essays on language function and language type (pp. 437-467). Amsterdam: John Benjamins.

Slobin, D. I. (2004). The many ways to search for a frog: linguistic typology and the expression of motion events. In S. Strömqvist \& L. Verhoeven (eds), Relating events in narrative: typological and contextual perspectives (pp. 219-257). Mahwah, NJ: Lawrence Erlbaum.

Slobin, D. I. (2006). What makes manner of motion salient? Explorations in linguistic typology, discourse, and cognition. In M. Hickmann \& S. Robert (eds), Space in languages: linguistic systems and cognitive categories (pp. 59-81). Amsterdam: John Benjamins. 


\section{VARIABLE MOTION EVENT ENCODING}

Slobin, D. I. \& Hoiting, N. (1994). Reference to movement in spoken and signed languages: typological considerations. In Proceedings of the Twentieth Annual Meeting of the Berkeley Linguistic Society (pp. 487-505). Online <https://journals.linguisticsociety.org/proceedings/ index.php/BLS/article/view/1466>.

Slobin, D. I., Ibarretxe-Antuñano, I., Kopecka, A. \& Majid, A. (2014). Manners of human gait: a crosslinguistic event-naming study. Cognitive Linguistics 25(4), 701-741.

Stam, G. (2006). Thinking for speaking about motion: L1 and L2 speech and gesture. International Review of Applied Linguistics in Language Teaching 44(2), 145-171.

Stefanowitsch, A. (2013). Variation and change in English path verbs and constructions: usage patterns and conceptual structure. In J. Goschler \& A. Stefanowitsch (eds), Variation and change in the encoding of motion events (pp. 223-245). Amsterdam: John Benjamins.

Strömqvist, S. \& Verhoeven (2004). Relating events in narrative: typological and contextual perspectives. Mahwah, NJ: Lawrence Erlbaum.

Talmy, L. (1978). Figure and ground in complex sentences. In J. H. Greenberg, C. A. Ferguson \& E. Moravcsik (eds), Universals of human language IV (pp. 627-649). Stanford, CA: Stanford University Press.

Talmy, L. (1991). Path to realization: a typology of event conflation. In Proceedings of the Seventeenth Annual Meeting of the Berkeley Linguistics Society (pp. 480-520). Online $<$ https://journals.linguisticsociety.org/proceedings/index.php/BLS/article/view/1620/0>.

Talmy, L. (2000). Toward a cognitive semantics II: typology and process in concept structuring. Cambridge, MA: MIT Press.

Tesnière, L. (1959). Éléments de syntaxe structural. Paris: Éditions Klincksieck.

Verkerk, A. (2013). Scramble, scurry and dash: the correlation between motion event encoding and manner verb lexicon size in Indo-European. Language Dynamics and Change 3(2), $169-217$.

Vinay, J.-P. \& Darbelnet, J. (1958). Stylistique comparée du français et de l'anglais. Paris: Didier. Whorf, B. L. (1956). Language, thought and reality (Carroll, J., ed.) Cambridge, MA: MIT Press. 


\section{Appendix I}

T A B LE 1. Sequence of events in the video stimulus

Man staggers down the stairs

Man ties a rope around his neck

Chaplin walks down the stairs

Chaplin pulls out a hankie

Man pulls a stone out of the case

The stone gets dropped

Chaplin undoes the noose from around the man's neck

Man throws a rope around both necks

Man throws a stone into the river

Chaplin falls into the water

Man steps forward

Man throws his jacket onto the ground

Man rushes to the river

Man lends Chaplin a hand

Chaplin pulls man into the water

Man pushes Chaplin toward shore

Man and Chaplin swim toward bank

Man reaches the bank

Man's grip slips on the bank

Chaplin steps on top of man's head

Man is submerged under water

Chaplin and man pull themselves up the bank

Man gets onto the ground

Man drags Chaplin out of the water

Man shakes Chaplin's hand

Man turns around

Man bends down

Man picks up his jacket

Chaplin turns around

Chaplin picks up his hat

Man steps backwards

Man pushes Chaplin into the water

Man turns around

Man throws his jacket onto the ground

Man jumps into the water

Chaplin steps on top of man's head

Chaplin and man reach the bank

Chaplin and man pull themselves up

Man gets out

Man pulls Chaplin out

Both walk toward the stairs

Chaplin walks back and picks up his flower

Both walk up the stairs 


\section{Appendix II}

T A B LE 2. Examples of self-and caused-motion descriptions produced by German native speakers

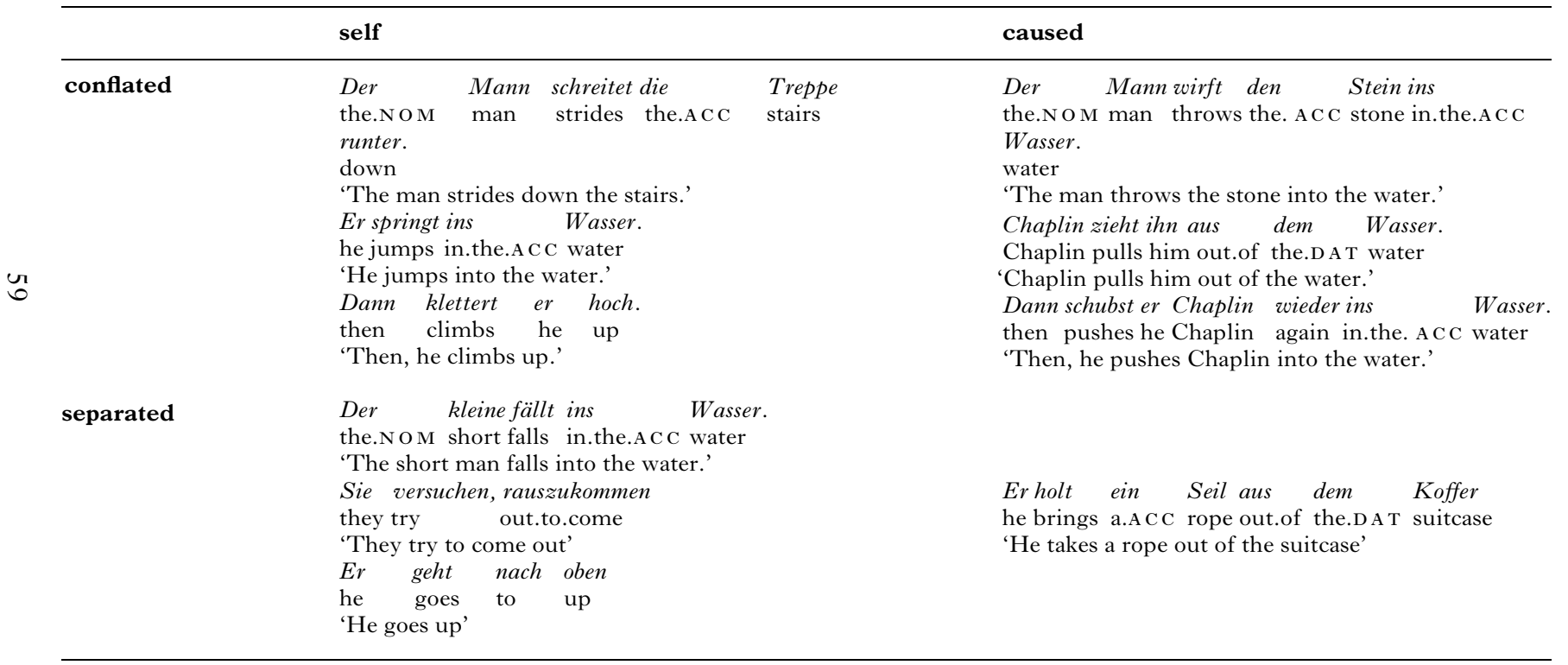


TA B LE 3. Examples of self- and caused-motion descriptions produced by Polish native speakers

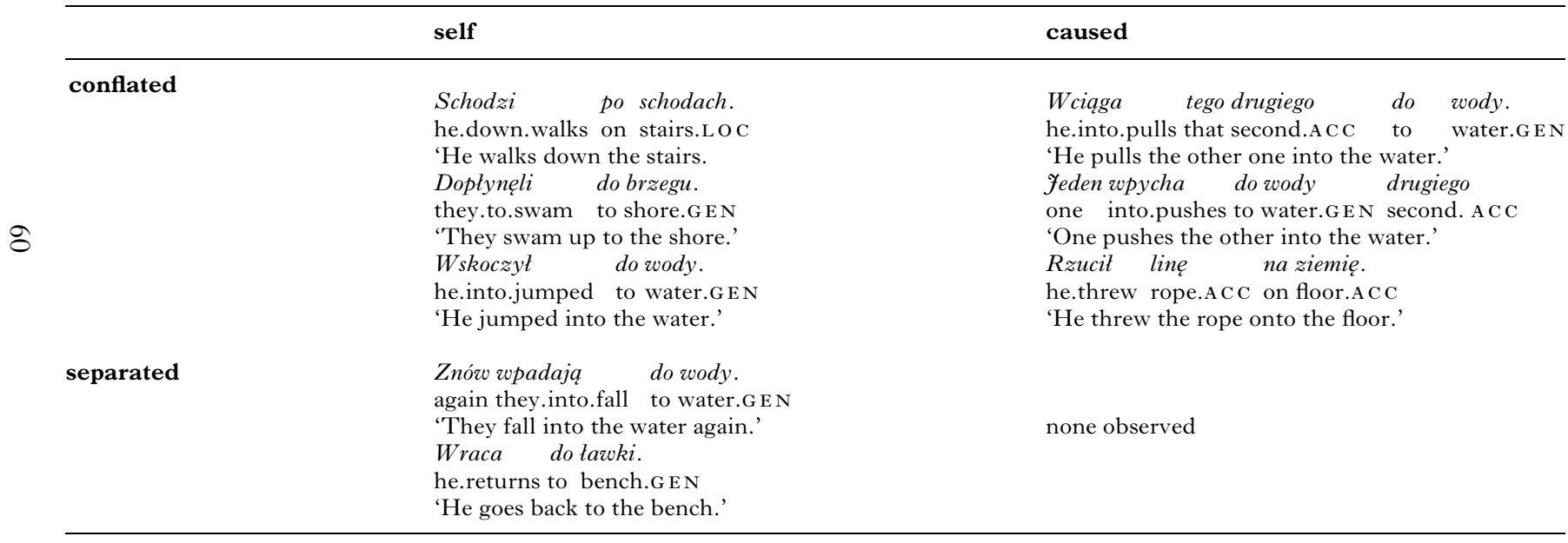


T A B LE 4. Examples of self-and caused-motion descriptions produced by Spanish native speakers

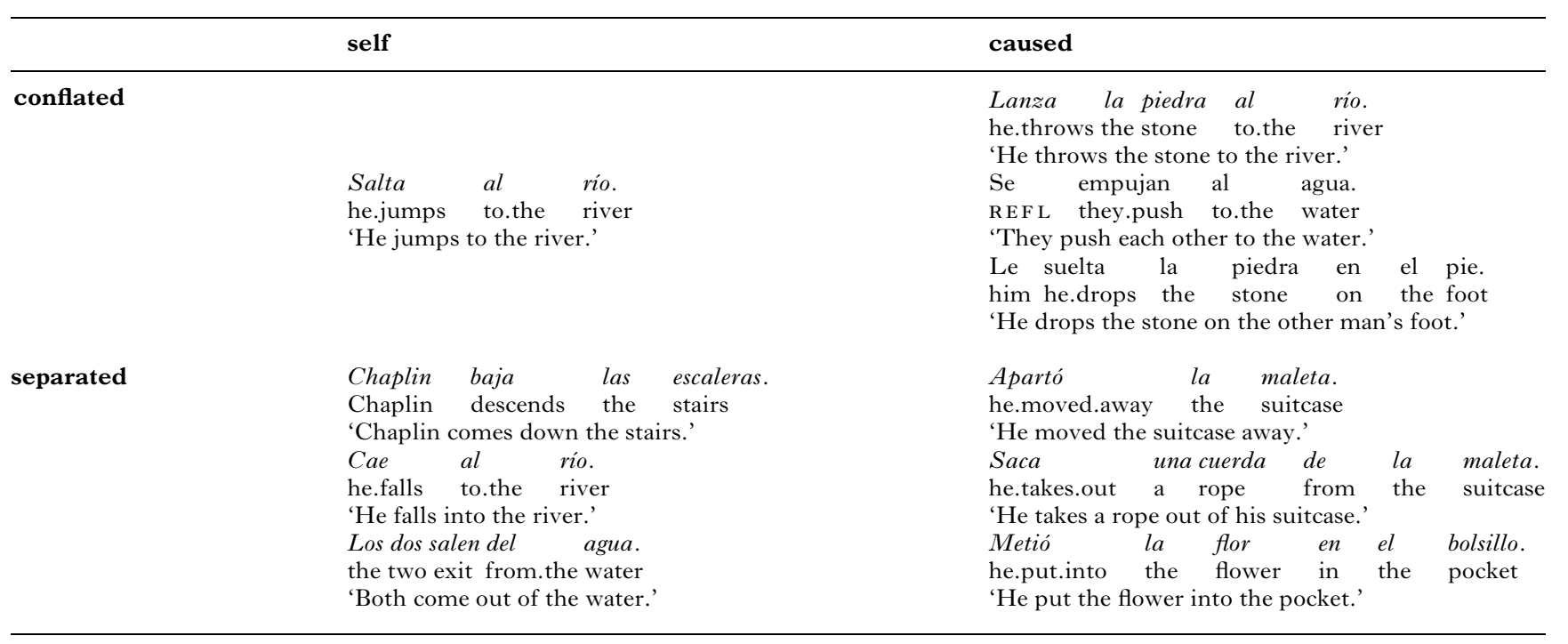

the two exit from.the wate 


\section{Appendix III}

T A B LE 5. Examples of Manner descriptions provided by German vs. Polish native speakers

\begin{tabular}{|c|c|c|}
\hline & German & Polish \\
\hline falling into the water & $\begin{array}{l}\text { Der Mann springt ins Wasser. } \\
\text { the man jumps in.the.ACC water } \\
\text { 'The man jumps into the water.' } \\
\text { Er fliegt ins Wasser. } \\
\text { he flies in.the.ACC water } \\
\text { 'He flies into the water.' } \\
\text { Er stürst ins Wasser. } \\
\text { he plunges in.the.AcC water } \\
\text { 'He plunges into the water.' } \\
\text { Chaplin rutscht ins Wasser. } \\
\text { Chaplin slips in.the.ACC water } \\
\text { 'Chaplin slips into the water.' }\end{array}$ & $\begin{array}{l}\text { Wskakuje do wody. } \\
\text { he.into.jumps to water.GEN } \\
\text { 'He jumps into the water.' } \\
\text { Rzuca sie do wody. } \\
\text { he.throws REFL to water.GEN } \\
\text { 'He plunges into the water.' }\end{array}$ \\
\hline coming out of the water & $\begin{array}{l}\text { Er klettert hoch. } \\
\text { he climbs up } \\
\text { 'He climbs up.' } \\
\text { Er krabbelt heraus. } \\
\text { he crawls out } \\
\text { 'He crawls out (of the water).' } \\
\text { Er hievt sich hoch. } \\
\text { he heaves REF L up } \\
\text { 'He heaves himself up.' } \\
\text { Er zieht sich hoch. } \\
\text { he pulls REF up } \\
\text { 'He pulls himself up. }\end{array}$ & $\begin{array}{l}\text { Wychodzi na brzeg. } \\
\text { he.out.walks on shore.ACC } \\
\text { 'He walks up to the shore.' } \\
\text { Wspina sie na brzeg. } \\
\text { he.into.climbs REF on shore.ACC } \\
\text { 'He climbs up to the shore.' }\end{array}$ \\
\hline moving away from shore & $\begin{array}{l}\text { Sie watscheln davon. } \\
\text { they waddle from.there } \\
\text { 'They waddle away.' } \\
\text { Er taumelt weg. } \\
\text { he reels away } \\
\text { 'He reels away.' } \\
\text { Sie torkeln zurück. } \\
\text { they stagger back } \\
\text { 'They stagger back.' } \\
\text { Beide schleichen davon. } \\
\text { both creep from.there } \\
\text { 'Both creep away.' }\end{array}$ & $\begin{array}{l}\text { Odchodza od brzegu. } \\
\text { they.away.walk from shore.GEN } \\
\text { 'They walk away from the shore' }\end{array}$ \\
\hline
\end{tabular}


TABLE 5. Continued

\begin{tabular}{|c|c|c|}
\hline & German & Polish \\
\hline throwing into water & $\begin{array}{l}\text { Er schmeißt Chaplin ins } \quad \text { Wasser. } \\
\text { he chucks Chaplin in.the.Acc water } \\
\text { 'He chucks Chaplin into the water.' } \\
\text { Er wirft Chaplin ins Wasser. } \\
\text { he throws Chaplin in.the.AcC water } \\
\text { 'He throws Chaplin into the water.' }\end{array}$ & $\begin{array}{l}\text { Wrzuca Chaplina do wody. } \\
\text { he.into.throws Chaplin.A C C to water.GEN } \\
\text { 'He throws Chaplin into the water.' }\end{array}$ \\
\hline pushing into water & $\begin{array}{l}\text { Er stößt Chaplin ins Wasser. } \\
\text { he.pushes Chaplin in.the. Acc water } \\
\text { 'He pushes Chaplin into the water.' } \\
\text { Er schubst Chaplin ins Wasser. } \\
\text { he shoves Chaplin in.the.ACC water } \\
\text { 'He shoves Chaplin into the water.' }\end{array}$ & $\begin{array}{l}\text { Wpycha Chaplina do wody. } \\
\text { he.into.pushes Chaplin.A c c to water.GEN } \\
\text { 'He pushes Chaplin into the water.' }\end{array}$ \\
\hline pulling out of water & $\begin{array}{l}\text { Er zieht ihn aus dem Wasser. } \\
\text { he pulls him out.of the.D A T water } \\
\text { 'He pulls him out of the water.' } \\
\text { Er hievt ihn aus dem Wasser. } \\
\text { he heaves him out.of the.D A T water } \\
\text { 'He heaves him out of the water.' }\end{array}$ & $\begin{array}{l}\text { Wyciaga go } z \quad \text { wody. } \\
\text { he.out.pulls him out.of water.GE N } \\
\text { 'He pulls him out of the water.' }\end{array}$ \\
\hline
\end{tabular}




\section{Appendix IV}

T A B LE 6. Mean number of clauses with separated (i.e., Path-only or Path and Manner in separate clauses) and conflated (i.e., Manner and Path in a single clause) packaging of motion components produced by German, Polish, or Spanish speakers

\begin{tabular}{lllll}
\hline & Separated & & Conflated \\
\hline & Path-only & Path E Manner & All & \\
\hline \multirow{2}{*}{ Merman } & Mean (SD) & Mean (SD) & Mean (SD) & Mean (SD) \\
& 14.67 & none & 14.67 & 13.6 \\
Polish & $(4.4)$ & observed & $(4.4)$ & $(2.92)$ \\
& 8.07 & none & 8.07 & 15.47 \\
Spanish & $(3.15)$ & observed & $(3.15)$ & $(4.52)$ \\
& 23.93 & 0.33 & 24.27 & 2.47 \\
& $(5.01)$ & $(0.63)$ & $(5.26)$ & $(1.85)$ \\
\hline
\end{tabular}

\section{Appendix V}

T A B LE 7. Manner and path verbs used by German, Polish, and Spanish speakers

\begin{tabular}{ll}
\hline Manner verb & Path verb \\
\hline German & \\
self & self \\
fahren 'drive' & kallen 'fall' \\
fliegen 'fly' & \\
hieven 'heave' & caused \\
humpeln 'hobble' & holen 'bring' \\
hüpfen 'hop' & \\
klettern 'climb' & \\
krabbeln 'crawl' & \\
kriechen 'creep' & \\
laufen 'run' & \\
rennen 'run' & \\
rudern 'paddle' & \\
rutschen 'slip' & \\
schleichen 'creep, sneak' \\
schreiten 'stride' \\
schwanken 'totter' \\
schwimmen 'swim' \\
springen 'jump' \\
stolpern 'stumble' \\
stüren 'plunge' \\
taumeln 'reel' \\
torkeln 'stagger' \\
watscheln 'waddle'
\end{tabular}


TABLE 7. Continued

\begin{tabular}{|c|c|}
\hline Manner verb & Path verb \\
\hline \multicolumn{2}{|l|}{$\begin{array}{l}\text { caused } \\
\text { drücken 'press' } \\
\text { führen 'guide, lead' } \\
\text { packen 'pack' } \\
\text { reißen 'tear' } \\
\text { shieben 'thrust' } \\
\text { schmeißen 'chuck' } \\
\text { schubsen 'push, nudge' } \\
\text { stoßen 'push, bump' } \\
\text { werfen 'throw' } \\
\text { zerren 'drag' } \\
\text { ziehen 'pull' } \\
\text { Polish }\end{array}$} \\
\hline $\begin{array}{l}\text { self } \\
\text { biec 'run' } \\
\text { chodzić 'walk' } \\
\text { gramolić się 'scramble' } \\
\text { kiwać sie 'totter' } \\
\text { plywać 'swim' } \\
\text { rzucić się 'plunge' } \\
\text { skakać 'jump' } \\
\text { wspinać się 'climb' } \\
\text { caused } \\
\text { ciagnać 'pull' } \\
\text { nieśc 'carry' } \\
\text { pchać 'push' } \\
\text { prowadzić 'guide, lead' } \\
\text { rzucać 'throw' } \\
\text { upuścić 'drop' } \\
\text { Spanish }\end{array}$ & $\begin{array}{l}\text { self } \\
\text { paść 'fall' } \\
\text { caused } \\
\text { none observed }\end{array}$ \\
\hline $\begin{array}{l}\text { self } \\
\text { caminar 'walk' } \\
\text { saltar 'jump' } \\
\text { tirarse 'plunge' } \\
\text { trepar 'climb' } \\
\text { caused } \\
\text { empujar 'push' } \\
\text { lanzar 'throw' } \\
\text { tirar }_{1} \text { 'pull' } \\
\text { tirar }_{2} \text { 'throw' }\end{array}$ & $\begin{array}{l}\text { self } \\
\text { acercarse 'approach' } \\
\text { alejarse 'go away' } \\
\text { bajar 'descend' } \\
\text { caer 'fall' } \\
\text { llegar 'arrive' } \\
\text { meterse 'enter' } \\
\text { salir 'exit' } \\
\text { subir 'ascend' } \\
\text { venir 'come' } \\
\text { volver 'return' }\end{array}$ \\
\hline & $\begin{array}{l}\text { caused } \\
\text { apartar 'set aside' } \\
\text { meter 'insert' } \\
\text { quitar 'remove' } \\
\text { sacar 'take out' } \\
\text { traer 'bring' }\end{array}$ \\
\hline
\end{tabular}

